\title{
Effects of high-starch or high-fat diets formulated to be isoenergetic on energy and nitrogen partitioning and utilization in lactating Jersey cows
}

\author{
D. L. Morris, ${ }^{1}{ }^{\oplus}$ T. M. Brown-Brandl, ${ }^{2}$ K. E. Hales, ${ }^{3} \odot$ K. J. Harvatine,${ }^{4}$ and P. J. Kononoff ${ }^{1 *}$ () \\ ${ }^{1}$ Department of Animal Science, University of Nebraska, Lincoln 68583 \\ ${ }^{2}$ Department of Biological Systems Engineering, University of Nebraska, Lincoln 68583 \\ ${ }^{3}$ Department of Animal and Food Sciences, Texas Tech University, Lubbock 79409 \\ ${ }^{4}$ Department of Animal Science, The Pennsylvania State University, University Park 16802
}

\section{ABSTRACT}

The objective of this study was to determine the effects of high-starch or high-fat diets formulated to be isoenergetic on energy and $\mathrm{N}$ partitioning and utilization of energy. Twelve multiparous Jersey cows (mean \pm standard deviation; $192 \pm 11 \mathrm{~d}$ in milk; $467 \pm 47 \mathrm{~kg}$ ) in a crossover design with 28 -d periods (24-d adaptation and 4-d collection) were used to compare 2 treatment diets. Treatments were high starch (HS; 30.8\% starch, $31.8 \%$ neutral detergent fiber, and $1.9 \%$ fatty acids) or high fat (HF; $16.8 \%$ starch, $41.7 \%$ neutral detergent fiber, and $4.1 \%$ fatty acids). Diets were formulated to have net energy for lactation $\left(\mathrm{NE}_{\mathrm{L}}\right)$ content of $1.55 \mathrm{Mcal} / \mathrm{kg}$ of dry matter according to the National Research Council (2001) dairy model. Nutrient composition was varied primarily by replacing corn grain in HS with a rumen-inert fat source and cottonseed hulls in HF. Gross energy content was lower for HS (4.43 vs. $4.54 \pm 0.01 \mathrm{Mcal} / \mathrm{kg}$ of dry matter), whereas digestible (2.93 vs. $2.74 \pm 0.035 \mathrm{Mcal} / \mathrm{kg}$ of dry matter) and metabolizable energy (2.60 vs. $2.41 \pm 0.030$ $\mathrm{Mcal} / \mathrm{kg}$ of dry matter), and $\mathrm{NE}_{\mathrm{L}}$ (1.83 vs. $1.67 \pm 0.036$ $\mathrm{Mcal} / \mathrm{kg}$ of dry matter) content were all greater than for HF. Tissue energy deposited as body fat tended to be greater for HS (4.70 vs. $2.14 \pm 1.01 \mathrm{Mcal} / \mathrm{d})$. For $\mathrm{N}$ partitioning, HS increased milk $\mathrm{N}$ secretion (141 vs. $131 \pm 10.5 \mathrm{~g} / \mathrm{d})$ and decreased urinary $\mathrm{N}$ excretion (123 vs. $150 \pm 6.4 \mathrm{~g} / \mathrm{d}$ ). Compared with HF, HS increased apparent total-tract digestibility of dry matter (66.7 vs. $61.7 \pm 1.06 \%)$, organic matter (68.5 vs. $63.2 \pm 0.98 \%)$, energy (66.0 vs. $60.4 \pm 0.92 \%)$, and 18-carbon fatty acids ( 67.9 vs. $61.2 \pm 1.60 \%$ ). However, apparent totaltract digestibility of starch decreased for HS from 97.0 to $94.5 \pm 0.48 \%$. Compared with HF, HS tended to

Received September 24, 2019.

Accepted January 20, 2020.

*Corresponding author: pkononoff2@unl.edu increase milk yield (19.7 vs. $18.9 \pm 1.38 \mathrm{~kg} / \mathrm{d}$ ), milk protein content (4.03 vs. $3.93 \pm 0.10 \%$ ), milk protein yield ( 0.791 vs. $0.740 \pm 0.050 \mathrm{~kg} / \mathrm{d})$, and milk lactose yield ( 0.897 vs. $0.864 \pm 0.067 \mathrm{~kg} / \mathrm{d})$. In addition, HS decreased milk fat content (5.93 vs. $6.37 \pm 0.15 \%)$ but did not affect milk fat yield (average of $1.19 \pm 0.09$ $\mathrm{kg} / \mathrm{d}$ ) or energy-corrected milk yield (average of 27.2 $\pm 1.99 \mathrm{~kg} / \mathrm{d}$ ). Results of the current study suggest that the HS diet had a greater metabolizable energy and $\mathrm{NE}_{\mathrm{L}}$ content, increased partitioning of $\mathrm{N}$ toward milk secretion and away from urinary excretion, and may have increased partitioning of energy toward tissue energy deposited as fat.

Key words: starch, fat, energy partitioning, nitrogen partitioning

\section{INTRODUCTION}

In diets formulated for lactating dairy cows, both starch (from grains and forages) and supplemental fat are often included as a source of energy. Although the enthalpy for starch $(4.2 \mathrm{Mcal} / \mathrm{kg}$ of DM) is lower than that of fatty acids (9.3 Mcal/kg of DM; NRC, 2001), the concentrations of these nutrients may be manipulated to produce isoenergetic diets (van Knegsel et al., 2007a,b; Boerman et al., 2015b). In addition to differing in the concentration of energy, energy from starch and fat may be assimilated by ruminants via different routes. Increasing dietary starch increases ruminal energy supply and supports microbial metabolism and rumen outflow of microbial protein (Roman-Garcia et al., 2016); however, approximately 35 to $45 \%$ of starch from corn bypass rumen digested and can directly supply energy. Fats are primarily utilized as a postabsorptive energy source and may be directly transferred to milk fat (Rico et al., 2014; Boerman et al., 2015b; Nichols et al., 2019). In low-starch, high-fat diets, dietary NDF is also often increased (van Knegsel et al., 2007a,b; Boerman et al., 2015b). Replacing a portion of 
starch with NDF and fatty acids will decrease production of propionate and increase production of acetate (Dijkstra, 1994; Sutton et al., 2003), thus decreasing supply of glucogenic substrates and increasing supply of lipogenic substrates. Given the differential effects of energy source on microbial protein synthesis, VFA production, and postabsorptive metabolism, the source of energy in a diet will affect both milk production and composition. However, the effect of energy source on whole-animal energy use is not well understood or completely characterized and as a result is difficult to predict (NRC, 2001). Additionally, models, such as the NRC (2001), are often used to formulate diets on an $\mathrm{NE}_{\mathrm{L}}$ basis, and evaluation of the predictive ability of these models is useful.

Studies that have evaluated the effects of starch or fat on milk production, composition, and metabolism often do so by feeding anisoenergetic diets, but several experiments have tested diets that were formulated to be isoenergetic (van Knegsel et al., 2005). In general, feeding isoenergetic diets with higher starch content (26-33\% of diet DM) compared with fat $(5.0-5.4 \%$ of diet DM) decreased milk fat concentration and yield and increased tissue energy (TE) in Holsteins (van Knegsel et al., 2007a,b; Boerman et al., 2015b). Milk protein yield increased when cows were fed an isoenergetic high-starch diet (Boerman et al., 2015b). However, in some studies where the inclusion of starch and fat was manipulated in isoenergetic diets, a response in milk protein was not observed (van Knegsel et al., 2007a,b). Consequently, the effects of increasing dietary starch in isoenergetic diets on animal $\mathrm{N}$ use and milk protein are not clear. Furthermore, increasing energy supply from fat may increase the efficiency at which $\mathrm{ME}$ is converted into $\mathrm{NE}_{\mathrm{L}}(\mathrm{NRC}, 2001)$ because incorporation of preformed fatty acids into milk fat is more energetically efficient than de novo lipogenesis (Kronfeld, 1982). Therefore, our objective was to determine the effect of an isoenergetic high-starch or high-fat diet on energy and $\mathrm{N}$ partitioning and efficiency of energy utilization in Jersey cows. We hypothesized that a high-starch diet would increase efficiency of converting dietary $\mathrm{N}$ into milk $\mathrm{N}$, and a high-fat diet would increase the utilization of energy for milk production by increasing efficiency of conversion of $\mathrm{ME}$ into $\mathrm{NE}_{\mathrm{L}}$.

\section{MATERIALS AND METHODS}

\section{Animals and Treatments}

The University of Nebraska-Lincoln Animal Care and Use Committee Animal approved animal care and experimental procedures. The experiment used 12 multiparous Jersey cows averaging $192 \pm 11$ DIM and $467 \pm 47 \mathrm{~kg}$ at the beginning of the experiment. Cows were housed in individual tiestalls equipped with rubber mats in a temperature-controlled $\left(20^{\circ} \mathrm{C}\right)$ barn at the Dairy Metabolism Facility in the Animal Science Complex at the University of Nebraska-Lincoln and milked at 0700 and $1800 \mathrm{~h}$. All cows were less than 135 d pregnant at the end of the last experimental period; thus, fetal energy was assumed to be zero (NRC, 2001).

The experimental design was a crossover with 2 periods of $28 \mathrm{~d}$. In period 1 , cows were randomly assigned to 1 of 2 treatment diets (6 cows per treatment): (1) high starch (HS) or (2) high fat (HF). For period 2, the alternative diet was fed. Concentrate mixes for each treatment that included all dietary ingredients except for forages and cottonseed hulls (Table 1) were mixed at the University of Nebraska-Lincoln feed mill. Corn silage, alfalfa hay, concentrate, and cottonseed hulls were added to a Calan Data Ranger (American Calan Inc., Northwood, NH), mixed, and fed as a TMR once daily at $0930 \mathrm{~h}$ with a target refusal rate of $5 \%$. Each period included $24 \mathrm{~d}$ of ad libitum diet adaptation, followed by $4 \mathrm{~d}$ of collection where diets were fed at $100 \%$ of the prior week's intake to limit refusals.

Experimental diets were formulated using NRC (2001) to contain differing amounts of starch, fat, and NDF while being isonitrogenous with a similar predicted $\mathrm{NE}_{\mathrm{L}}$ content (using measured DMI and dietary chemical composition; Table 1). Energy source was manipulated by including $22.5 \%$ of the $\mathrm{DM}$ as ground corn grain or supplementing at $2.6 \%$ of diet DM with a commercial rumen-inert fat (Energy Booster 100, Milk Specialties, Eden Prairie, MN). Isonitrogenous and isoenergetic diets were maintained by manipulating inclusion rate of soyhulls, soybean meal, nonenzymatically browned soybean meal, cottonseed hulls, and dried distillers grains with solubles. Additionally, diets were estimated to supply similar amounts of Lys, Met, and His (NRC, 2001).

\section{Sample Collection and Analysis}

Individual feed ingredients, which included corn silage, alfalfa hay, concentrate mixes, and cottonseed hulls, were sampled daily during collection periods and frozen at $-20^{\circ} \mathrm{C}$. Corn silage was dried at $60^{\circ} \mathrm{C}$ for 48 $\mathrm{h}$, and then all other feeds were ground to pass a 1-mm screen (Wiley mill, Arthur H. Thomas Co., Philadelphia, PA). A subsample of ground feed was sent to Cumberland Valley Analytical Services Inc. (Waynesboro, PA) for analysis of $\mathrm{N}$ (method 990.03; AOAC International, 2000), NDF with sodium sulfite (Van Soest et al., 1991) and $\alpha$-amylase and corrected for 
ash contamination $\left(\mathbf{N D F}_{\mathbf{O M}}\right)$, ADF (method 973.18; AOAC International, 2000), ADL (Goering and Van Soest, 1970), sugar (DuBois et al., 1956), starch (Hall, 2009), ash (943.05; AOAC International, 2000), and minerals (985.01; AOAC International, 2000). Additionally, feed ingredients were analyzed for gross energy (GE) content (Parr 6400 Calorimeter, Moline, IL) in the nutrition laboratory of the University of NebraskaLincoln and for long-chain fatty acid (LCFA) content and profile in the nutrition laboratory of the Penn State University as described by Rico et al. (2014). The chemical composition of diets and individual feed ingredients are listed in Tables 1 and 2, respectively. During each day of the collection period, refusals were sampled

Table 1. Ingredient and chemical composition of a high-starch (HS) or high-fat (HF) diet (\% of DM unless otherwise indicated $)^{1}$

\begin{tabular}{|c|c|c|}
\hline Item & HS & $\mathrm{HF}$ \\
\hline \multicolumn{3}{|l|}{ Ingredient } \\
\hline Corn silage & 38.1 & 38.1 \\
\hline Alfalfa hay & 21.0 & 21.0 \\
\hline Corn grain, dry ground & 22.5 & 2.5 \\
\hline Soyhulls & 4.1 & 6.5 \\
\hline Soybean meal & 11.5 & 10.9 \\
\hline Nonenzymatically browned soybean meal ${ }^{2}$ & - & 0.6 \\
\hline Cottonseed hulls & - & 12.5 \\
\hline Dried distillers grains and solubles & - & 2.5 \\
\hline $\mathrm{Fat}^{3}$ & - & 2.6 \\
\hline Rumen-protected Lys ${ }^{4}$ & 0.20 & 0.19 \\
\hline Rumen-protected Met ${ }^{5}$ & 0.16 & 0.17 \\
\hline Mineral-vitamin $\operatorname{mix}^{6}$ & 2.37 & 2.37 \\
\hline \multicolumn{3}{|l|}{ Chemical composition $^{7,8}$} \\
\hline DM & $61.1(0.09)$ & $61.8(0.21)$ \\
\hline $\mathrm{CP}$ & $15.5(0.52)$ & $16.0(0.35)$ \\
\hline $\mathrm{ADF}$ & $20.7(1.26)$ & $29.8(1.80)$ \\
\hline NDF & $31.8(3.19)$ & $41.7(1.90)$ \\
\hline $\mathrm{NDF}_{\mathrm{OM}}$ & $30.8(2.20)$ & $40.5(1.27)$ \\
\hline Starch & $30.8(0.42)$ & $16.8(0.85)$ \\
\hline Sugar & $2.34(0.47)$ & $2.27(0.19)$ \\
\hline LCFA & $1.88(0.02)$ & $4.06(0.14)$ \\
\hline $16 \mathrm{C}$ & $0.35(0.01)$ & $1.02(0.03)$ \\
\hline $18 \mathrm{C}$ & $1.48(0.01)$ & $2.86(0.10)$ \\
\hline $\mathrm{ROM}$ & $12.8(1.85)$ & $13.9(1.24)$ \\
\hline Ash & $7.3(0.12)$ & $7.5(0.13)$ \\
\hline $\mathrm{Ca}$ & $0.73(0.03)$ & $0.76(0.02)$ \\
\hline $\mathrm{P}$ & $0.40(0.01)$ & $0.40(0.01)$ \\
\hline $\mathrm{Mg}$ & $0.37(0.03)$ & $0.34(0.01)$ \\
\hline $\mathrm{K}$ & $1.62(0.03)$ & $1.79(0.05)$ \\
\hline $\mathrm{S}$ & $0.28(0.01)$ & $0.29(0.01)$ \\
\hline $\mathrm{Na}$ & $0.42(0.11)$ & $0.32(0.03)$ \\
\hline $\mathrm{Cl}$ & $0.28(0.01)$ & $0.32(0.03)$ \\
\hline $\mathrm{NE}_{\mathrm{J}},{ }^{9} \mathrm{Mcal} / \mathrm{kg}$ & 1.56 & 1.54 \\
\hline Lys, ${ }^{9} \mathrm{~g} / \mathrm{d}$ & 132 & 131 \\
\hline Met, $9 \mathrm{~g} / \mathrm{d}$ & 53 & 53 \\
\hline His, ${ }^{9} \mathrm{~g} / \mathrm{d}$ & 41 & 40 \\
\hline MP balance, ${ }^{9} \mathrm{~g} / \mathrm{d}$ & 52 & 110 \\
\hline
\end{tabular}

${ }^{1}$ Values in parentheses indicate SD $(\mathrm{n}=2)$.

${ }^{2}$ Soypass (LignoTech, Overland Park, KS).

${ }^{3}$ Energy Booster 100 (Milk Specialties, Eden Prairie, MN). According to manufacturer specifications, it contained $99 \%$ fatty acids $(31.2 \% 16: 0,47.7 \% 18: 0,9.9 \% 18: 1)$.

${ }^{4}$ Ajipro (Ajinomoto, Chicago, IL).

${ }^{5}$ Smartamine M (Adisseo, Alpharetta, GA).

${ }^{6}$ Contained per kilogram of premix: $245 \mathrm{~g}$ of $\mathrm{NaHCO}_{3}, 224 \mathrm{~g}$ of $\mathrm{CaCO}_{3}, 148 \mathrm{~g}$ of $\mathrm{CaHPO}_{4}, 127 \mathrm{~g}$ of salt, $127 \mathrm{~g}$ of $\mathrm{MgO}, 97 \mathrm{~g}$ of $\mathrm{NaSO}_{4}, 21 \mathrm{~g}$ of vitamin premix $(14,850 \mathrm{IU} / \mathrm{g}$ vitamin $\mathrm{A}, 3,850 \mathrm{IU} / \mathrm{g}$ vitamin $\mathrm{D}$, and $90 \mathrm{IU} / \mathrm{g}$ vitamin E), and $13 \mathrm{~g}$ of trace mineral premix $(180,000 \mathrm{mg} / \mathrm{kg} \mathrm{Zn}, 150,000 \mathrm{mg} / \mathrm{kg} \mathrm{Mn}, 25,000 \mathrm{mg} / \mathrm{kg} \mathrm{Cu}, 2,600$ $\mathrm{mg} / \mathrm{kg} \mathrm{I}, 2,300 \mathrm{mg} / \mathrm{kg} \mathrm{Co}, 1,000 \mathrm{mg} / \mathrm{kg} \mathrm{Fe}$, and $820 \mathrm{mg} / \mathrm{kg} \mathrm{Se})$.

${ }^{7} \mathrm{NDF}_{\mathrm{OM}}=\mathrm{NDF}-\mathrm{NDF}$ ash; LCFA = long-chain fatty acids; residual organic matter $(\mathrm{ROM})=100-\% \mathrm{CP}-$ \%LCFA - \%Ash - \%Starch - \%NDF

${ }^{8}$ Values determined by Cumberland Valley Analytical Services, Waynesboro, PA; values denoted as mean (SD). ${ }^{9}$ Calculated with NRC (2001) using measured dietary nutrient composition for forage and cottonseed hulls from Table 2 and mean DMI, and milk production and composition from Table 6. 
Table 2. Chemical composition of corn silage, alfalfa hay, concentrate mixes, and cottonseed hulls (\% of DM unless otherwise indicated) ${ }^{1}$

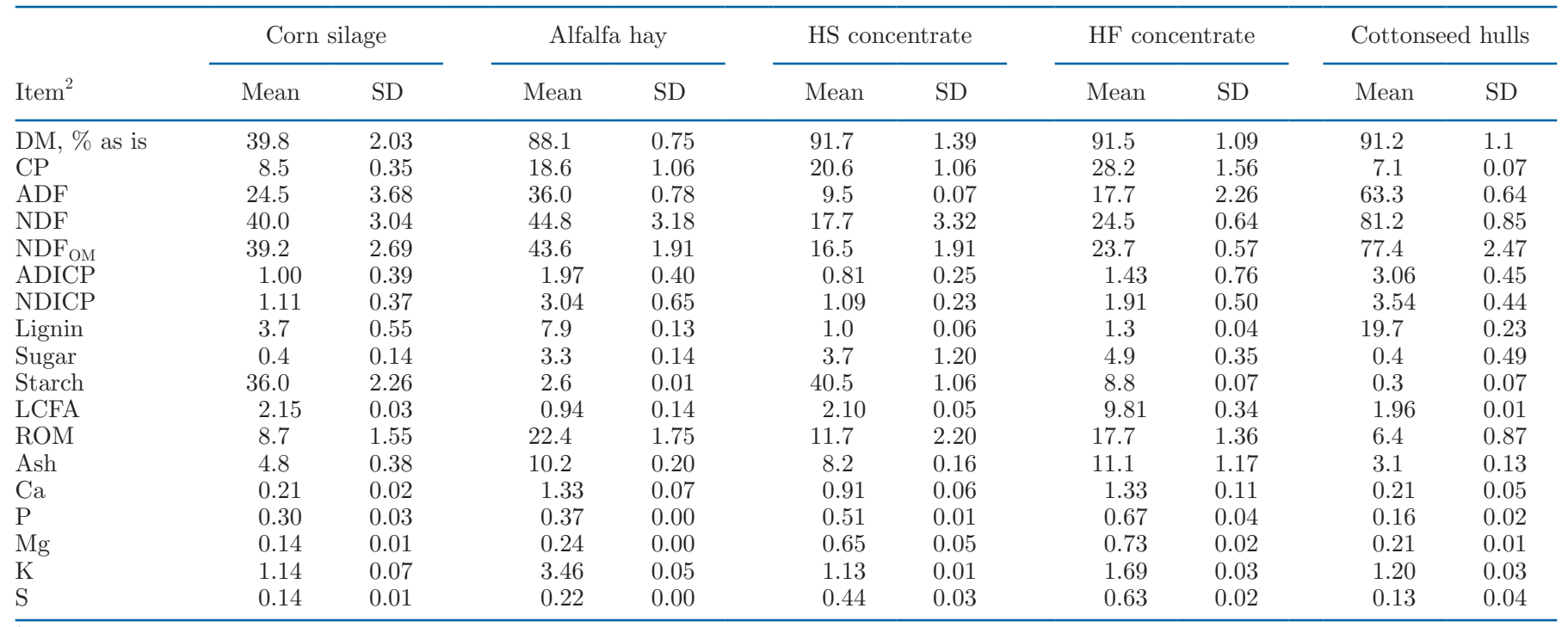

${ }^{1} \mathrm{n}=2 . \mathrm{HS}=$ high starch; HF $=$ high fat.

${ }^{2} \mathrm{ADICP}=$ acid detergent insoluble crude protein; NDICP $=$ neutral detergent insoluble crude protein; $\mathrm{NDF}_{\mathrm{OM}}=\mathrm{NDF}-\mathrm{NDF}$ ash; LCFA $=$ long-chain fatty acids; residual organic matter $(\mathrm{ROM})=100-\% \mathrm{CP}-\% \mathrm{LCFA}-\% \mathrm{Ash}-\% \mathrm{Starch}-\% \mathrm{NDF}$.

and composited on a wet-weight basis. Refusals were analyzed for N, NDF, $\mathrm{NDF}_{\mathrm{OM}}$, starch, ash, GE, and LCFA via the same methods as feeds.

Total fecal and urine output was collected from each individual cow during the collection period for 4 consecutive days. A $137 \times 76 \mathrm{~cm}$ rubber mat was placed behind the cow to aid in fecal collection. Feces were manually collected by personnel during defecation or were picked up from the rubber mat and deposited into a trash can (Rubbermaid, Wooster, $\mathrm{OH}$ ) with a trash bag covering the top to minimize $\mathrm{N}$ losses before subsampling. Daily feces were subsampled ( $\sim 500 \mathrm{~g}$ as is), composited on a wet-weight basis, and frozen between collection events. After collections, feces were dried at $60^{\circ} \mathrm{C}$ for $48 \mathrm{~h}$ and ground to pass through a 1-mm screen (Wiley mill, Arthur H. Thomas Co.). The ground feces samples were analyzed as described for refusals. Total urine was collected by inserting a 30-French Foley catheter into each cow's bladder with a stylus. The balloon was inflated to $55 \mathrm{~mL}$ with physiological saline. The catheter was drained into a 55 -L plastic container via Tygon tubing (Saint Gobain, La Defense, Courbevoie, France). Acid $(50 \% \mathrm{HCl})$ was added to the urine collection container at the beginning of the collection day. Urine $\mathrm{pH}$ was measured at the end of each day and the quantity of acid used was adjusted to maintain a $\mathrm{pH}$ $<5$. Urine was subsampled daily and composited on a wet-weight basis. Urine samples were frozen $\left(-20^{\circ} \mathrm{C}\right)$ until later analysis. Urine GE was determined by drying approximately $4 \mathrm{~mL}$ of the sample in a bomb capsule until just dry $(4 \mathrm{~h})$ and then combusting the sample (Parr 6400 Calorimeter, Moline, IL). Urine N on the liquid sample was determined by Cumberland Valley Analytical Services Inc. (Waynesboro, PA) using a Leco FP-528 N Combustion Analyzer (Leco Corp., St. Joseph, MI).

Cows were weighed, before feeding, on the first and last day of the collection periods. Milk production was measured daily, and milk samples were collected during both the morning and evening milking of collection periods. Milk from individual milking events was preserved with 2-bromo-2-nitropropane-1,3 diol and sent to Heart of America DHIA (Kansas City, MO). Milk samples were analyzed for fat, protein, lactose, SNF, MUN, and SCC using a Bentley FTS/FCM Infrared Analyzer (Bentley Instruments, Chaska, MN). Additionally, milk from each milking event was composited on a weight basis. Composited milk samples were analyzed for GE and $\mathrm{N}$ as described previously for urine except $1 \mathrm{~mL}$ of milk was used to determine GE.

Heat production was determined through the headbox-type indirect calorimeters as described previously (Freetly et al., 2006; Foth et al., 2015). For each cow, a collection period of $23 \mathrm{~h}$ was used to measure $\mathrm{O}_{2}$ consumption and $\mathrm{CO}_{2}$ and $\mathrm{CH}_{4}$ production. Gas data were adjusted to a 24 -h period. Four headboxes were used and data were collected across $3 \mathrm{~d}$ during the 4-d collection period. Feed was placed in the bottom of the headbox and cows were allowed ad libitum access to water from a water bowl placed inside the headbox. Free 
water intake was measured using a water meter (model DLJSJ75, Daniel L. Jerman Co., Hackensack, NJ) while each cow was inside the headbox. Within the headbox, temperature and dew point were measured every minute during the 23-h collection interval using a probe (model TRH-100, Pace Scientific Inc., Moorseville, NC) and recorded using a data logger (model XR440, Pace Scientific Inc.). Line pressure was measured using a utube manometer (item 1221-8, Park Supply of America Inc., Minneapolis, MN) and barometric pressure of the room was measured using a barometer (Chaney Instruments Co., Lake Geneva, WI). Total volume of air flow through the headbox was measured using a gas meter (model AL425, American Meter, Horsham, PA) and corrected to standard temperature and pressure $\left(0^{\circ} \mathrm{C}, 760 \mathrm{mmHg}\right)$ with adjustment for moisture content of exhaust air (Nienaber and Maddy, 1985). From the headbox, continuous samples of incoming and outgoing air were collected into separate aluminum Mylar bags (44 L, LAM-JAPCON-NSE, Pollution Measurement Corp., Oak Park, IL) using glass tube rotameters (model 1350E Sho-Rate "50," Brooks Instruments, Hatfield, PA). Gas bags were analyzed for $\mathrm{O}_{2}, \mathrm{CO}_{2}$ and $\mathrm{CH}_{4}$ using an Emerson X-stream 3-channel analyzer (Solon, $\mathrm{OH}$ ) according to the method of Nienaber and Maddy (1985). Heat production was estimated as follows (Brouwer, 1965):

$$
\begin{aligned}
& \text { heat production }(\mathrm{kcal} / \mathrm{d})=3.866 \times \mathrm{O}_{2}(\mathrm{~L} / \mathrm{d}) \\
& +1.200 \times \mathrm{CO}_{2}(\mathrm{~L} / \mathrm{d})-0.518 \times \mathrm{CH}_{4}(\mathrm{~L} / \mathrm{d})-1.431 \\
& \times \text { Urinary N excretion }(\mathrm{g} / \mathrm{d}) .
\end{aligned}
$$

The respiratory quotient (RQ) was calculated using the ratio of carbon dioxide produced to oxygen consumed $(\mathrm{L} / \mathrm{L})$. Methane energy was estimated by multiplying $\mathrm{CH}_{4}$ production by its enthalpy $(9.45 \mathrm{kcal} / \mathrm{L})$. Unaccounted for energy was assumed to represent mobilization or accretion of whole-animal TE, which was expressed as $\mathrm{NE}_{\mathrm{L}}$ (NRC, 2001) and partitioned into body protein and fat energy (NRC, 2001; Freetly et al., 2006; van Knegsel et al., 2007a). Calculations were as follows:

$$
\begin{gathered}
\text { digestible energy }(\mathbf{D E} ; \mathrm{Mcal} / \mathrm{d})=\mathrm{GE}(\mathrm{Mcal} / \mathrm{d}) \\
- \text { fecal energy }(\mathrm{Mcal} / \mathrm{d}),
\end{gathered}
$$

$\operatorname{ME}(\mathrm{Mcal} / \mathrm{d})=\operatorname{DE}(\mathrm{Mcal} / \mathrm{d})-$ urine energy $(\mathrm{Mcal} / \mathrm{d})$

$$
\text { - methane energy (Mcal/d), }
$$

residual energy $(\mathrm{Mcal} / \mathrm{d})=\mathrm{ME}(\mathrm{Mcal} / \mathrm{d})-$ heat production $(\mathrm{Mcal} / \mathrm{d})$ - milk energy $(\mathrm{Mcal} / \mathrm{d}), \quad$ [4]
TE $\left(\right.$ Mcal of $\left.\mathrm{NE}_{\mathrm{L}} / \mathrm{d}\right)=$ positive residual energy $\times 0.82$ or negative residual energy/1.12,

tissue energy as body protein $\left(\mathbf{T E}_{\mathbf{P}} ; \mathrm{Mcal} / \mathrm{d}\right)=$ retained $\mathrm{N}(\mathrm{g} / \mathrm{d}) \times 5.88(\mathrm{~g}$ of protein $/ \mathrm{g}$ of $\mathrm{N})$

$$
\times 0.0057 \text { (Mcal/g of protein), }
$$

tissue energy as body fat $\left(\mathbf{T E}_{\mathbf{F}} ; \mathrm{Mcal} / \mathrm{d}\right)=$

$$
\mathrm{TE}(\mathrm{Mcal} / \mathrm{d})-\mathrm{TE}_{\mathrm{P}}(\mathrm{Mcal} / \mathrm{d}) \text {, }
$$

$\mathrm{NE}_{\mathrm{L}}(\mathrm{Mcal} / \mathrm{d})=$ milk energy $\left(\right.$ Mcal of $\left.\mathrm{NE}_{\mathrm{L}} / \mathrm{d}\right)$

$+\mathrm{TE}\left(\right.$ Mcal of $\left.\mathrm{NE}_{\mathrm{L}} / \mathrm{d}\right)+0.080 \times \mathrm{BW}(\mathrm{kg})^{0.75}$.

Before the start of the experiment, system efficiency (head box and gas analyzer) was determined by burning 100\% ethyl alcohol and measuring gas recoveries. Recoveries of $\mathrm{O}_{2}$ and $\mathrm{CO}_{2}$ were (average \pm SD) $93.5 \pm$ 1.57 and $91.4 \pm 3.44 \%$, respectively.

\section{Statistical Analysis}

Data were analyzed in R (v3.4.1) using the lmer (Kuznetsova et al., 2017) package. The model included the fixed effect of treatment and the random effect of period, cow, and error. Denominator degrees of freedom were calculated using the Kenward-Roger option of the anova function. All data are presented as least squares means \pm largest standard error. Significance and trends were declared at $P \leq 0.05$ and $P \leq 0.15$, respectively.

\section{RESULTS AND DISCUSSION}

This experiment was designed to test the effects of a feeding an isoenergetic high-starch or high-fat diet on energy and $\mathrm{N}$ partitioning and efficiency of energy utilization. Previous research with Holsteins suggests that a high-starch diet compared with isoenergetic high-fat diets will decrease milk fat yield and increase energy utilization for body reserves (van Knegsel et al., 2007a,b; Boerman et al., 2015b). Furthermore, increasing energy supply from fat is thought to increase the efficiency at which $\mathrm{ME}$ is converted into $\mathrm{NE}_{\mathrm{L}}$ (NRC, 2001). Feeding starch as an energy source compared with fat in isoenergetic diets increased milk protein yield in some (Boerman et al., 2015b) but not in other studies (van Knegsel et al., 2007a,b). The reason for this discrepancy is unclear, but if increased starch increases milk protein yield, $\mathrm{N}$ excretion may decrease. Therefore, we expected that HS would result in the diversion of $\mathrm{N}$ toward milk and away from urine, whereas 
HF would increase the utilization of energy for milk production by increasing efficiency of conversion of ME into milk energy.

\section{Gas Consumption and Production and Energy Partitioning and Utilization}

One cow refused to eat while in the headboxes during training before the experiment. Thus, fecal and urine output, DMI, milk production and composition, BW, and BCS were collected, but this cow was not placed in a headbox and thus gas measurements were not made. We tested the effects of placing animals in the headboxes on DMI by comparing DMI on the day cows were placed inside the headboxes with the days they were not. Dry matter intake did not differ $(P=0.47)$ when cows were either in or out of the headboxes (17.7 vs. $18.0 \pm 0.58 \mathrm{~kg} / \mathrm{d}$; data not shown). This observation is similar to a previous experiment at the University of Nebraska where DMI was not affected by placing cows in headboxes (Judy et al., 2018).

In general, the oxidation of lipids, protein, and carbohydrates results in an RQ of $0.71,0.81$, and 1.00 , respectively, whereas an RQ greater than 1 is associated with lipid synthesis (Blaxter, 1989). In the current study, the RQ was greater $(P<0.01)$ for cows fed HS (1.09 vs. $1.05 \pm 0.012$; Table 3 ), suggesting that lipid synthesis was greater for cows fed HS. Previously, abomasal infusion of glucose increased RQ while an isoenergetic abomasal infusion of palm olein (primarily palmitic, oleic, and linoleic acid) decreased RQ in Holsteins (Nichols et al., 2019). In support of increased lipid synthesis for cows consuming HS compared with $\mathrm{HF}$, estimated whole-animal $\mathrm{TE}_{\mathrm{F}}$ tended $(P=0.11)$ to be higher for HS (4.33 vs. $1.93 \pm 0.94 \mathrm{Mcal} / \mathrm{d})$. When feeding isoenergetic diets over wk 1 to 7 of lactation, van Knegsel et al. (2007a) observed that whole-animal $\mathrm{TE}_{\mathrm{F}}$ was greater in a high-starch $(27 \%$ starch, $3.4 \%$ crude fat, and $32 \%$ NDF) than a high-fat diet $(10 \%$ starch, $5.4 \%$ crude fat, and $40 \% \mathrm{NDF}$ ). Boerman et al. (2015b) reported increased yield of milk fatty acids of de novo origin and increased body fat thickness when feeding mid-lactation dairy cows a high-starch diet $(32 \%$ starch, $3.2 \%$ fatty acids, and $25 \% \mathrm{NDF}$ ) compared with an isoenergetic high-fat diet (16\% starch, $5.4 \%$ fatty acids, and 33\% NDF). Increasing supply of glucogenic precursors typically increases circulating insulin (Rius et al., 2010, Cantalapiedra-Hijar et al., 2014; Boerman et al., 2015b), which would signal for increased lipid synthesis in peripheral tissue. It is worth noting that RQ data from ruminants should be interpreted with caution because a small fraction of $\mathrm{CO}_{2}$ originates from rumen fermentation and thus is not a direct product of substrate metabolism in the animal, and $\mathrm{CO}_{2}$ may be liberated or sequestered from the bicarbonate pool to maintain metabolic $\mathrm{pH}$ (Brody, 1945). However, the consistency between RQ and whole-animal $\mathrm{TE}_{\mathrm{F}}$ data suggest that HS compared with HF increased energy partitioning toward lipid stores, which is supported by similar observations from the literature (van Knegsel et al., 2007a; Boerman et al., 2015b). Additionally, because dietary $\mathrm{NE}_{\mathrm{L}}$ was greater for $\mathrm{HS}$ (see later discussion), increased $\mathrm{TE}_{\mathrm{F}}$ may not have occurred due to starch, but due to increased energy content.

Although differences between diets were not detected for daily consumption of any energy fractions, when energy fractions were expressed per kilogram of DMI, differences were observed (Table 3). This discrepancy occurred because DMI is an important contributor to the variation in supply of each energy fraction and accounting for DMI resulted in a decrease in SEM (4.4 vs. $1.2 \%$ of mean). The GE content was lower $(P<0.01)$ for HS (4.43 vs. $4.54 \pm 0.012 \mathrm{Mcal} / \mathrm{kg}$ of DM) due to a lower LCFA content $(1.88 \pm 0.02$ vs. $4.06 \pm 0.14 \%$ of $\mathrm{DM})$. Because cottonseed hulls are poorly digested, DE content was expected to be similar across diets (NRC, $2001)$; however, DE content was greater $(P<0.01)$ for HS (2.93 vs. $2.74 \pm 0.035 \mathrm{Mcal} / \mathrm{d})$, which suggests that digestibility of corn grain in HS was greater than expected or digestibility of cottonseed hulls in HF was lower than expected. Fecal energy output was greater $(P<0.01)$ for HF $(31.7$ vs. $26.0 \pm 1.16 \mathrm{Mcal} / \mathrm{d})$. Consistent with $\mathrm{DE}, \mathrm{ME}$ and $\mathrm{NE}_{\mathrm{L}}$ content were greater $(P$ $\leq 0.01$ ) for HS (2.60 vs. $2.41 \pm 0.03 \mathrm{Mcal}$ of ME/d and 1.83 vs. $1.67 \pm 0.036 \mathrm{Mcal}$ of $\left.\mathrm{NE}_{\mathrm{L}} / \mathrm{d}\right)$. The efficiency of converting DE to ME was greater $(P=0.05)$ for HS (0.888 vs. $0.876 \pm 0.003)$ due to decreased $(P=$ $0.04)$ urinary energy loss (2.07 vs. $2.44 \pm 0.11 \mathrm{Mcal} / \mathrm{d})$. The decreased urinary energy excretion for cows fed HS was due to decreased urinary $\mathrm{N}$ excretion (see later discussion).

Diets were formulated to contain similar $\mathrm{NE}_{\mathrm{L}}$ contents (averaging 1.55 Mcal of $\mathrm{NE}_{\mathrm{L}} / \mathrm{kg}$ of DM; NRC, 2001); however, as discussed previously, observed $\mathrm{NE}_{\mathrm{L}}$ was greater in the HS treatment and both diets exceeded NRC (2001) estimated $\mathrm{NE}_{\mathrm{L}}$ (average measured $\mathrm{NE}_{\mathrm{L}}$ of $1.77 \mathrm{Mcal} / \mathrm{kg}$ of DM), which was due to cumulative error in the estimated energy lost with the conversion of $\mathrm{DE}$ to $\mathrm{ME}$, and $\mathrm{ME}$ to $\mathrm{NE}_{\mathrm{L}}$. To better understand the discrepancy between observed $\mathrm{NE}_{\mathrm{L}}$ and NRC (2001), estimated $\mathrm{NE}_{\mathrm{L}}, \mathrm{DE}$, and $\mathrm{ME}$ were calculated using $\mathrm{NRC}$ (2001) equations. Dietary fat is included as a variable in NRC (2001) to estimate transformation of DE to ME and $\mathrm{ME}$ to $\mathrm{NE}_{\mathrm{L}}$; however, the inclusion of fat as a variable did not appear to improve accuracy in estimating $\mathrm{DE}, \mathrm{ME}$, and $\mathrm{NE}_{\mathrm{L}}$. Because accuracy in estimating $\mathrm{DE}$, 
$\mathrm{ME}$, and $\mathrm{NE}_{\mathrm{L}}$ was similar across diets, only $\mathrm{HS}$ will be discussed. For HS, observed DE was similar to NRC (2001) estimated DE, 2.93 vs. $2.91 \mathrm{Mcal} / \mathrm{kg}$ of DM, respectively. The efficiency of energy transfer from $\mathrm{DE}$ to ME for HS when using NRC estimates was 0.877 , whereas we observed an DE to ME efficiency of 0.888 \pm 0.003 (Table 3). The use of a fixed conversion factor $(\mathrm{ME}=1.01 \times \mathrm{DE}-0.45$ for diets with less than $3.0 \%$ crude fat; NRC, 2001) does not account for the effects that diet, milk production, and intake have on gas and urinary energy losses. The NRC (2001) estimated MEto- $\mathrm{NE}_{\mathrm{L}}$ efficiency of 0.621 for HS, whereas the observed efficiency was $0.703 \pm 0.008$. Similar to the conversion of DE to ME, NRC (2001) uses a fixed conversion of
$0.703 \times \mathrm{ME}-0.19$ for the conversion of $\mathrm{ME}$ to $\mathrm{NE}_{\mathrm{L}}$ for diets with less than $3.0 \%$ crude fat. In addition, because whole-animal $\mathrm{TE}$ in the current study was calculated by difference, this fraction may accumulate error associated with determining other fractions and consequently lead to an overestimation of TE. Nonetheless, on average, the TE values for the current study correspond to a reasonable $\mathrm{BW}$ gain of about $0.6 \mathrm{~kg} / \mathrm{d}$ (assuming 5.84 Mcal $\mathrm{NE}_{\mathrm{L}} / \mathrm{kg}$ of $\mathrm{BW}$ gain when $\mathrm{BCS}$ equals 3.5; NRC, 2001). Therefore, an overestimation of TE may explain some but not all of the discrepancy between NRC (2001) estimated and observed $\mathrm{NE}_{\mathrm{L}}$, and thus the equations for calculating $\mathrm{NE}_{\mathrm{L}}$ may need to be revisited. Heat increment, which is the difference in ME

Table 3. Effects of a high-starch (HS) or high-fat (HF) diet fed to lactating Jersey cows on energy partitioning and utilization

\begin{tabular}{|c|c|c|c|c|}
\hline \multirow[b]{2}{*}{ Item $^{1,2}$} & \multicolumn{2}{|c|}{ Treatment $^{3,4}$} & \multirow[b]{2}{*}{$\mathrm{SEM}^{4}$} & \multirow[b]{2}{*}{$P$-value } \\
\hline & HS & $\mathrm{HF}$ & & \\
\hline \multicolumn{5}{|l|}{ Gas } \\
\hline $\mathrm{O}_{2}$ consumption, $\mathrm{L} / \mathrm{d}$ & 4,048 & 4,120 & 136 & 0.59 \\
\hline $\mathrm{CO}_{2}$ production, $\mathrm{L} / \mathrm{d}$ & 4,410 & 4,345 & 193 & 0.67 \\
\hline $\mathrm{CH}_{4}$ production, L/d & 391 & 388 & 27 & 0.83 \\
\hline $\mathrm{RQ}$ & 1.09 & 1.05 & 0.012 & $<0.01$ \\
\hline \multicolumn{5}{|l|}{ Component, Mcal/d } \\
\hline Feces & 26.0 & 31.7 & 1.16 & $<0.01$ \\
\hline Methane & 3.70 & 3.66 & 0.26 & 0.83 \\
\hline Urine & 2.07 & 2.44 & 0.11 & 0.04 \\
\hline $\mathrm{HP}$ & 20.6 & 20.7 & 0.74 & 0.81 \\
\hline Milk & 19.1 & 18.9 & 1.48 & 0.82 \\
\hline $\mathrm{TE}$ & 4.89 & 2.51 & 1.08 & 0.16 \\
\hline $\mathrm{TE}_{\mathrm{P}}$ & 0.53 & 0.50 & 0.25 & 0.92 \\
\hline $\mathrm{TE}_{\mathrm{F}}$ & 4.33 & 1.93 & 0.94 & 0.11 \\
\hline \multicolumn{5}{|l|}{ Fraction, Mcal/d } \\
\hline GE & 76.7 & 80.0 & 3.23 & 0.20 \\
\hline $\mathrm{DE}$ & 50.7 & 48.3 & 2.56 & 0.23 \\
\hline $\mathrm{ME}$ & 46.4 & 43.5 & 1.88 & 0.18 \\
\hline $\mathrm{NE}_{\mathrm{L}}^{5}$ & 32.8 & 30.1 & 1.32 & 0.19 \\
\hline \multicolumn{5}{|l|}{ Fraction, Mcal/ $\mathrm{kg}$ of DM } \\
\hline GE & 4.43 & 4.54 & 0.012 & $<0.01$ \\
\hline $\mathrm{DE}$ & 2.93 & 2.74 & 0.035 & $<0.01$ \\
\hline $\mathrm{ME}$ & 2.60 & 2.41 & 0.030 & $<0.01$ \\
\hline $\mathrm{NE}_{\mathrm{L}}$ & 1.83 & 1.67 & 0.036 & 0.01 \\
\hline \multicolumn{5}{|l|}{ Efficiency } \\
\hline $\mathrm{ME} / \mathrm{DE}$ & 0.888 & 0.876 & 0.003 & 0.05 \\
\hline Milk/ME & 0.428 & 0.454 & 0.017 & 0.26 \\
\hline $\mathrm{HP} / \mathrm{ME}$ & 0.449 & 0.478 & 0.014 & 0.19 \\
\hline $\mathrm{TE} / \mathrm{ME}$ & 0.100 & 0.055 & 0.020 & 0.16 \\
\hline $\mathrm{TE}_{\mathrm{P}} / \mathrm{ME}$ & 0.010 & 0.013 & 0.005 & 0.70 \\
\hline $\mathrm{TE}_{\mathrm{F}} / \mathrm{ME}$ & 0.090 & 0.042 & 0.018 & 0.10 \\
\hline $\mathrm{NE}_{\mathrm{L}} / \mathrm{ME}$ & 0.703 & 0.694 & 0.008 & 0.47 \\
\hline
\end{tabular}

${ }^{1} \mathrm{RQ}=$ respiratory quotient $\left(\mathrm{CO}_{2}\right.$ production $/ \mathrm{O}_{2}$ consumption, $\left.\mathrm{L} / \mathrm{L}\right) ; \mathrm{HP}=$ heat production $\left[3.866 \times \mathrm{O}_{2}+\right.$ $1.200 \times \mathrm{CO}_{2}-0.518 \times \mathrm{CH}_{4}-1.431 \times \mathrm{N}$ (Brouwer, 1965$\left.)\right] ; \mathrm{TE}=$ tissue energy; $\mathrm{TE}_{\mathrm{P}}=$ tissue energy as body protein; $\mathrm{TE}_{\mathrm{F}}=$ tissue energy as body fat.

${ }^{2}$ Milk yield, DMI, and BW measured during collection period (Table 6) were used to calculate corresponding energy components and fractions.

${ }^{3} \mathrm{n}=24$ for feces, urine, milk, gross energy (GE), and digestible energy (DE), $\mathrm{n}=22$ for all other variables.

${ }^{4}$ Least squares means; largest standard error of treatment mean is listed.

${ }^{5} \mathrm{NE}_{\mathrm{L}}=0.080 \times \mathrm{BW}^{0.75}+$ milk energy + tissue energy corrected for efficiency of conversion to milk energy (NRC, 2001). 
and $\mathrm{NE}_{\mathrm{L}}$, is the aggregate of the heat associated with digestion and absorption, fermentation, production formation, waste synthesis, and excretion (NRC, 1981). The use of an equation that incorporates animal variation, nutrient flux, and product formation to estimate heat increment may be more accurate than assuming a constant conversion of $\mathrm{ME}$ to $\mathrm{NE}_{\mathrm{L}}$.

We hypothesized that HF would increase the efficiency of ME utilization for milk production because incorporation of dietary fat into milk is more energetically efficient than de novo lipogenesis (Baldwin et al., 1985). However, the efficiency of converting ME into milk energy was not different $(P=0.26)$ between diets, averaging $0.441 \pm 0.17$. Similarly, the efficiency of converting $\mathrm{ME}$ into $\mathrm{NE}_{\mathrm{L}}$ was not different $(P=0.39)$ between diets, averaging $0.699 \pm 0.008$. In an energy balance experiment, the estimated efficiency of $\mathrm{ME}$ from supplemental fat as Ca-salts was 0.774 (Andrew et al., 1991). Although this is greater than the average ME-to- $\mathrm{NE}_{\mathrm{L}}$ efficiency that we observed, increased fatty acid supply from the HF diet only accounted for approximately $5 \%$ of ME supply assuming a $100 \%$ conversion of DE from fatty acids into ME. Thus, the effect of supplemental fat on ME-to- $\mathrm{NE}_{\mathrm{L}}$ efficiency may have been negligible or too small to observe.

\section{Nitrogen Partitioning and Utilization}

Evaluation of how $\mathrm{N}$ is partitioned can be useful in determining how dietary $\mathrm{N}$ is used for productive, maintenance, or metabolic functions. Urinary N excretion decreased $(P<0.04)$ for HS compared with HF on a mass basis (123 vs. $150 \pm 6.4 \mathrm{~g} / \mathrm{d}$; Table 4 ), or when expressed as a function of $\mathrm{N}$ intake (28.7 vs. 33.3 $\pm 1.38 \%)$. A decrease in urinary $\mathrm{N}$ excretion in cows consuming HS occurred as a result of $\mathrm{N}$ being diverted toward milk secretion and away from urinary excretion. In the current study, feeding HS compared with HF increased $(P<0.03)$ milk $\mathrm{N}$ secretion on a mass basis (141 vs. $131 \pm 10.5 \mathrm{~g} / \mathrm{d})$ and when expressed as a function of $\mathrm{N}$ intake (32.3 vs. $28.8 \pm 1.05 \%$ ). With abomasal infusion of wheat starch to Holsteins, Reynolds et al. (2001) observed decreased urinary N excretion; yet, inconsistent with our results, milk $\mathrm{N}$ excretion was not affected and retained $\mathrm{N}$ increased with wheat starch infusion. In the current study, retained $\mathrm{N}$ did not differ $(P=0.98)$. The discrepancy between the current study and Reynolds et al. (2001) may have occurred because our treatments were applied through dietary manipulation, whereas Reynolds et al. (2001) directly infused wheat starch into the abomasum. Compared with HF, HS may have stimulated microbial protein synthesis and thus increased intestinal absorption of
EAA, which may have caused the increased milk $\mathrm{N}$ secretion. Similar to our results, an increase in milk N efficiency was observed with isoenergetic abomasal infusions of glucose compared with palm olein (Nichols et al., 2019). However, these investigators attributed the increase in milk $\mathrm{N}$ efficiency to a decrease in $\mathrm{N}$ intake with the glucose infusion. The partitioning of $\mathrm{N}$ toward milk and away from urine in cows fed HS may be due to increased AA availability to the mammary gland and increased utilization efficiency of AA by the mammary gland (Cantalapiedra-Hijar et al., 2014, 2015), which may be mediated by an upregulation of protein synthesis via insulin and energy substrates (Rius et al., 2010). Increased utilization of AA for milk protein synthesis would explain why a decrease in urinary $\mathrm{N}$ excretion was observed.

\section{Nutrient Digestibility}

Feeding HS increased $(P<0.01)$ apparent DM and OM digestibility ( 66.7 vs. $61.7 \pm 1.06$ and 68.5 vs. 63.2 $\pm 0.95 \%$, respectively, Table 5). Boerman et al. (2015b) observed a greater DM digestibility in their high-starch diet. Increased DM and OM digestibility for HS can mostly be attributed to the replacement of a less digestible carbohydrate $\left(\mathrm{NDF}_{\mathrm{OM}}\right.$, average digestibility of $45.5 \pm 1.38 \%$ ) with a highly digestible carbohydrate (starch, average digestibility of $95.9 \pm 0.48 \%$ ). Simi-

Table 4. Effects of a high-starch or high-fat diet fed to lactating Jersey cows on fecal and urinary output and $\mathrm{N}$ excretion, secretion, and utilization

\begin{tabular}{lccrr}
\hline & \multicolumn{2}{c}{ Treatment $^{2,3}$} & & \\
\cline { 2 - 3 } Item $^{1}$ & HS & HF & SEM $^{3}$ & P-value \\
\hline Output, kg/d & & & & \\
Feces, as is & 79.7 & 86.5 & 3.56 & $<0.01$ \\
Feces, DM & 5.73 & 6.76 & 0.24 & $<0.01$ \\
Urine, as is & 23.0 & 25.5 & 2.46 & $<0.01$ \\
Mass, g/d & & & & \\
N intake & 434 & 455 & 21.4 & 0.16 \\
Fecal N & 154 & 158 & 6.7 & 0.52 \\
Urinary N & 123 & 150 & 6.4 & $<0.01$ \\
Milk N & 141 & 131 & 10.5 & 0.03 \\
Retained N & 16 & 15 & 7.3 & 0.92 \\
As proportion of & & & & \\
N intake, \% & & & & 0.23 \\
Fecal N & 35.6 & 34.8 & 1.02 & 0.04 \\
Urinary N & 28.7 & 33.3 & 1.38 & 0.01 \\
Milk N & 32.3 & 28.8 & 1.05 & $<4$ \\
Retained N & 3.3 & 3.1 & 1.52 & 0.94 \\
\hline
\end{tabular}

${ }^{1}$ Milk yield and DMI measured during collection period (Table 6) were used to calculate corresponding $\mathrm{N}$ fractions.

${ }^{2} \mathrm{HS}=$ high-starch diet; $\mathrm{HF}=$ high-fat diet.

${ }^{3}$ Least squares means; largest standard error of treatment mean is listed. 
larly, when replacing starch with NDF, DM and OM digestibility decreased, whereas NDF digestibility was unchanged in Holsteins (Beckman and Weiss, 2005). Consistent with DM and OM digestibility, energy digestibility was greater $(P<0.01)$ for HS $(66.0$ vs. 60.4 $\pm 0.92 \%)$. However, starch digestibility increased $(P$ $<0.01$ ) from 94.5 to $97.0 \pm 0.48 \%$ for HS and HF, respectively. The effects of dietary manipulation on starch digestibility in the literature are variable. Starch digestibility has been shown to increase with decreasing dietary NDF (Firkins et al., 2001) and increasing dietary starch content (Weiss et al., 2009). However, this would suggest increased starch digestibility for HS in the current experiment. Source of starch can also influence starch digestibility. For example, in a metaanalysis, the digestibility of starch from high-moisture corn was on average about 2 percentage units greater than dry-ground or rolled corn (Ferraretto et al., 2013). In the current study, starch from corn silage provided about $46 \%$ of the dietary starch for HS and about $88 \%$ of the dietary starch for HF. Therefore, a lower starch digestibility for the ground corn compared with corn silage could result in a lower overall starch digestibility for HS. Although total LCFA and 16-carbon fatty acid digestibility was not different $(P>0.18)$ between diets, digestibility of 18 -carbon fatty acids decreased $(P<$ $0.01)$ for HF compared HS (61.2 vs. $67.9 \pm 1.60 \%)$. The HF diet increased 16-carbon fatty acids in the diet by 0.67 percentage units and 18-carbon fatty acids by 1.38 percentage units. Increasing duodenal fatty acid flow, especially 18:0, is known to decrease fatty acid digestibility (Boerman et al., 2015a). Decreased digestibility of 18-carbon fatty acids with the same supplement used in HF was recently reported in Holsteins (de Souza et al., 2018). Stearic acid is the predominant fatty acid escaping the rumen and additional supplementation may have decreased intestinal digestibility of this fatty acid.

\section{DMI, Milk Yield, and Milk Composition}

Although our objectives included measurement of energy partitioning toward body reserves, BW changes was not reported in the current experiment because changes in BW may not necessarily reflect changes in TE (Moe et al., 1971; NRC, 2001). This is particularly a problem in crossover experimental designs where any change in DMI that may occur with dietary change is measured in BW. Milk yield tended $(P=0.12)$ to increase from 18.9 to $19.7 \pm 1.38$ with HS in the current experiment (Table 6). Boerman et al. (2015b) observed increased milk yield when feeding mid-lactation cows a high-starch diet compared with an isoenergetic high-fat diet. Milk lactose production also tended $(P=0.15)$ to
Table 5. Effects of a high-starch (HS) or high-fat (HF) diet fed to lactating Jersey cows on total-tract digestibility (\%)

\begin{tabular}{lllcr}
\hline & \multicolumn{2}{c}{ Treatment $^{3}$} & & \\
\cline { 2 - 3 } Item $^{1,2}$ & HS & HF & SEM $^{3}$ & P-value \\
\hline DM & 66.7 & 61.7 & 1.06 & $<0.01$ \\
OM & 68.5 & 63.2 & 0.98 & $<0.01$ \\
NDF & 43.7 & 43.8 & 1.09 & 0.93 \\
NDF & 45.3 & 45.5 & 1.38 & 0.87 \\
CP & 64.4 & 65.2 & 1.02 & 0.23 \\
Starch & 94.5 & 97.0 & 0.48 & $<0.01$ \\
LCFA & 63.7 & 60.5 & 1.57 & 0.18 \\
16C & 63.1 & 63.8 & 1.32 & 0.72 \\
18C & 67.9 & 61.2 & 1.60 & $<0.01$ \\
ROM & 72.5 & 79.9 & 2.96 & $<0.01$ \\
Energy & 66.0 & 60.4 & 0.92 & $<0.01$ \\
\hline
\end{tabular}

${ }^{1} \mathrm{NDF}_{\mathrm{OM}}=\mathrm{NDF}-\mathrm{NDF}$ ash; LCFA = long-chain fatty acids; residual organic matter $(\mathrm{ROM})=100-\% \mathrm{CP}-\% \mathrm{LCFA}-\%$ Ash $-\%$ Starch $-\% \mathrm{NDF}$.

${ }^{2}$ Nutrient digestibilities were calculated using DMI measured during the collection period (Table 6).

${ }^{3}$ Least squares means; largest standard error of treatment mean is listed.

increase from 0.86 to $0.90 \pm 0.07 \mathrm{~kg} / \mathrm{d}$ for HS. Boerman et al. (2015b) observed increased milk lactose production when feeding a high-starch diet to Holsteins. Because milk lactose is a major osmotic driver of milk yield (Linzell and Peaker, 1971), increased lactose synthesis typically increases milk yield. Although milk yield increased with HS, ECM was not different $(P=$ 0.84 ), averaging $27.2 \pm 1.99$.

Table 6. Effects of a high-starch (HS) or high-fat (HF) diet fed to lactating Jersey cows on intake, milk production and composition, free water intake, BW, and BCS

\begin{tabular}{|c|c|c|c|c|}
\hline \multirow[b]{2}{*}{ Item } & \multicolumn{2}{|c|}{ Treatment $^{1,2}$} & \multirow[b]{2}{*}{$\mathrm{SEM}^{3}$} & \multirow[b]{2}{*}{$P$-value } \\
\hline & HS & $\mathrm{HF}$ & & \\
\hline DMI, $\mathrm{kg} / \mathrm{d}$ & 17.3 & 17.6 & 0.75 & 0.55 \\
\hline Milk yield, $\mathrm{kg} / \mathrm{d}$ & 19.7 & 18.9 & 1.38 & 0.12 \\
\hline $\mathrm{ECM}^{3} \mathrm{~kg} / \mathrm{d}$ & 27.2 & 27.1 & 1.99 & 0.84 \\
\hline Fat, \% & 5.93 & 6.37 & 0.15 & $<0.01$ \\
\hline Fat, $\mathrm{kg} / \mathrm{d}$ & 1.17 & 1.20 & 0.094 & 0.29 \\
\hline Protein, \% & 4.03 & 3.93 & 0.10 & 0.13 \\
\hline Protein, $\mathrm{kg} / \mathrm{d}$ & 0.791 & 0.740 & 0.050 & 0.07 \\
\hline Lactose, \% & 4.55 & 4.57 & 0.042 & 0.60 \\
\hline Lactose, $\mathrm{kg} / \mathrm{d}$ & 0.897 & 0.864 & 0.067 & 0.15 \\
\hline MUN, mg/dL & 9.78 & 9.70 & 0.16 & 0.50 \\
\hline Free water intake, L/d & 73.0 & 79.2 & 5.60 & 0.03 \\
\hline $\mathrm{BW},{ }^{4} \mathrm{~kg}$ & 467 & 467 & 13 & 0.92 \\
\hline $\mathrm{BCS}^{5}$ & 3.38 & 3.42 & 0.071 & 0.21 \\
\hline
\end{tabular}

${ }^{1} \mathrm{n}=22$ for free water intake, $\mathrm{n}=24$ for all other variables.

${ }^{2}$ Least squares means; largest standard error of treatment mean is listed.

${ }^{3} \mathrm{ECM}=0.327 \times$ milk yield $(\mathrm{kg})+12.95 \times$ fat $(\mathrm{kg})+7.20 \times$ true protein $(\mathrm{kg})$ (Tyrrell and Reid, 1965).

${ }^{4}$ Average from 2 measurements during last $4 \mathrm{~d}$ of each period.

${ }^{5}$ Scored 1 to 5 by 2 independent observations. 
Decreased milk fat production when feeding an isoenergetic high-starch diet compared with a high-fat or high-fiber diet (or both) to Holsteins has been observed in several studies (van Knegsel et al., 2007a,b; Boerman et al., 2015b). This response is usually attributed to the partitioning of energy away from milk at the expense of body tissue energy. Although milk fat concentration decreased $(P<0.01)$ from 6.37 to $5.93 \pm 0.15 \%$ with HS, milk fat yield was not different $(P=0.29)$ between diets. Thus, the decreased milk fat concentration for HS may be due to a dilution effect cause by increased milk yield. Additionally, the profile of FA in fat supplements are known to affect milk production; de Souza et al. (2018) observed that milk fat yield increased when feeding a predominantly palmitic acid fat source compared with the same palmitic and stearic blend as used in the current study.

Compared with HF, concentration of milk protein tended $(P=0.13)$ to increase from 3.93 to $4.03 \pm$ $0.10 \%$ and milk protein yield tended $(P=0.07)$ to increase from 0.74 to $0.79 \pm 0.05 \mathrm{~kg} / \mathrm{d}$. When feeding isoenergetic high-starch compared with a high-fat diet, Boerman et al. (2015b) observed increased milk protein yield by $0.10 \mathrm{~kg} / \mathrm{d}$, whereas van Knegsel et al., (2007a,b) observed no response. However, the use of early-lactation cows in the latter study may explain the difference. Piccioli-Cappelli et al. (2014) observed increased milk protein yield with increased dietary starch content in late-lactation cows (190 DIM) but not in early-lactation cows (30 DIM). Increasing supply of glucogenic precursors typically increases plasma insulin (Rius et al., 2010; Cantalapiedra-Hijar et al., 2014; Boerman et al., 2015b), which may increase milk protein synthesis in the mammary gland (Rius et al., 2010). However, during early lactation insulin resistance may increase (De Koster and Opsomer, 2013). Nonetheless, the current study was not designed to test the effect of stage of lactation. The increased milk protein yield with HS in the current study may be multifaceted. First, increased starch supply may have increased microbial protein synthesis - an enriched source of Lys and Met (Sok et al., 2017). Using the dietlevel equation (i.e., DMI and dietary starch content as parameters) of Roman-Garcia et al. (2016), estimated microbial N flow was 252 and $237 \mathrm{~g} / \mathrm{d}$ for HS and HF, respectively. Second, increased whole-body supply of glucogenic precursors may spare utilization of AA as an energy source and increase utilization of AA for milk protein synthesis. Specially, feeding isoenergetic diets with starch compared with NDF as an energy source to Jerseys increased net splanchnic release of AA, posthepatic availability of AA, and mammary utilization of EAA for milk protein synthesis (Cantalapiedra-Hijar et al., 2014, 2015). However, these authors concluded that the increased utilization of dietary $\mathrm{N}$ for milk is not from an AA sparing effect per se, but rather decreased energy requirement of the portal-drained viscera and increased duodenal flow of microbial N. Additionally, the energy content $\left(\mathrm{NE}_{\mathrm{L}}\right.$ and $\left.\mathrm{ME}\right)$ was greater for HS, which may have caused the increased milk protein production and confounded the interpretation of the effects of energy source in isoenergetic diets on milk protein production. Our results suggest that not only energy supply, but also composition of energy supply may influence milk protein synthesis and should be considered in future nutritional models. For example, increased supply of starch as an energy source tended to increase milk protein production.

\section{CONCLUSIONS}

Feeding a high-starch versus a high-fat diet did not affect total ME intake, but increased overall dietary $\mathrm{ME}$ content, increased milk $\mathrm{N}$ secretion and decreased urinary $\mathrm{N}$ excretion. Feeding starch as an energy source also tended to increase estimated whole-animal deposition of tissue energy as fat. Compared with the NRC (2001) model, observed dietary $\mathrm{NE}_{\mathrm{L}}$ content was greater primarily due to increased conversion of $\mathrm{ME}$ into $\mathrm{NE}_{\mathrm{L}}$. As hypothesized, feeding a high-starch compared with a high-fat diet tended to increase milk protein; however, efficiency of energy utilization for milk was not different. Milk fat content but not yield increased when feeding a high-fat diet. Results from the current study suggest that source of energy supply may influence milk protein production and $\mathrm{N}$ partitioning.

\section{ACKNOWLEDGMENTS}

The authors thank the University of Nebraska Dairy Metabolism (Lincoln, NE) staff and students for care of the experimental animals and assistance with collections and B. Compton (USDA Meat Animal Research Center, Clay Center, NE) for assistance with gas analysis. This research was not funded by an external source; funding originated from general operating funds. For the last 3 years, P. J. Kononoff has received research funding from the Nebraska Corn Board and Milk Specialties Global (MSG, Eden Prairie, MN) and has received honoraria from presenting to employees of MSG. Authors have not stated any other conflicts of interest.

\section{REFERENCES}

Andrew, S. M., H. Tyrrell, C. Reynolds, and R. Erdman. 1991. Net energy for lactation of calcium salts of long-chain fatty acids for 
cows fed silage-based diets. J. Dairy Sci. 74:2588-2600. https://doi .org/10.3168/jds.S0022-0302(91)78437-3.

AOAC International. 2000. Official Methods of Analysis. Vol. 1 and 2. 17th ed. AOAC International, Gaithersburg, MD.

Baldwin, B. R., N. E. Forsberg, and C. Y. Hu. 1985. Potential for altering energy partition in the lactating cow. J. Dairy Sci. 68:33943402. https://doi.org/10.3168/jds.S0022-0302(85)81252-2.

Beckman, J. L., and W. P. Weiss. 2005. Nutrient digestibility of diets with different fiber to starch ratios when fed to lactating dairy cows. J. Dairy Sci. 88:1015-1023. https://doi.org/10.3168/jds .S0022-0302(05)72769-7.

Blaxter, K. 1989. Energy Metabolism in Animals and Man. Cambridge University Press, Cambridge, UK.

Boerman, J. P., J. L. Firkins, N. R. St-Pierre, and A. L. Lock. 2015a. Intestinal digestibility of long-chain fatty acids in lactating dairy cows: A meta-analysis and meta-regression. J. Dairy Sci. 98:88898903. https://doi.org/10.3168/jds.2015-9592.

Boerman, J. P., S. B. Potts, M. J. VandeHaar, and A. L. Lock. 2015b. Effects of partly replacing dietary starch with fiber and fat on milk production and energy partitioning. J. Dairy Sci. 98:7264-7276. https://doi.org/10.3168/jds.2015-9467.

Brody, S. 1945. Bioenergetics and Growth. Reinhold Publishing Corporation, New York, NY.

Brouwer, E. 1965. Report of sub-committee on constants and factors. Pages 441-443 in Proceedings of the 3rd Symposium of Energy Metabolism. K. L. Blaxter, ed. Academic Press, London, UK.

Cantalapiedra-Hijar, G., S. Lemosquet, J. M. Rodriguez-Lopez, F. Messad, and I. Ortigues-Marty. 2014. Diets rich in starch increase the posthepatic availability of amino acids in dairy cows fed diets at low and normal protein levels. J. Dairy Sci. 97:5151-5166. https: //doi.org/10.3168/jds.2014-8019.

Cantalapiedra-Hijar, G., I. Ortigues-Marty, and S. Lemosquet. 2015. Diets rich in starch improve the efficiency of amino acids use by the mammary gland in lactating Jersey cows. J. Dairy Sci. 98:6939-6953. https://doi.org/10.3168/jds.2015-9518. https://doi .org/10.3168/jds.2015-9518

De Koster, J. D., and G. Opsomer. 2013. Insulin resistance in dairy cows. Vet. Clin. North Am. Food Anim. Pract. 29:299-322. https: //doi.org/10.1016/j.cvfa.2013.04.002.

de Souza, J., C. Preseault, and A. Lock. 2018. Altering the ratio of dietary palmitic, stearic, and oleic acids in diets with or without whole cottonseed affects nutrient digestibility, energy partitioning, and production responses of dairy cows. J. Dairy Sci. 101:172-185. https://doi.org/10.3168/jds.2017-13460.

Dijkstra, J. 1994. Production and absorption of volatile fatty acids in the rumen. Livest. Prod. Sci. 39:61-69. https://doi.org/10.1016/ 0301-6226(94)90154-6.

DuBois, M., K. A. Gilles, J. K. Hamilton, P. Rebers, and F. Smith. 1956. Colorimetric method for determination of sugars and related substances. Anal. Chem. 28:350-356. https://doi.org/10.1021/ ac60111a017.

Ferraretto, L. F., P. Crump, and R. Shaver. 2013. Effect of cereal grain type and corn grain harvesting and processing methods on intake, digestion, and milk production by dairy cows through a meta-analysis. J. Dairy Sci. 96:533-550. https://doi.org/10.3168/ jds.2012-5932.

Firkins, J., M. Eastridge, N. St-Pierre, and S. Noftsger. 2001. Effects of grain variability and processing on starch utilization by lactating dairy cattle. J. Anim. Sci. 79(E-Suppl):E218-E238. https://doi .org/10.2527/jas2001.79E-SupplE218x.

Foth, A. J., T. Brown-Brandl, K. J. Hanford, P. S. Miller, G. Garcia Gomez, and P. J. Kononoff. 2015. Energy content of reduced-fat dried distillers grains with solubles for lactating dairy cows. J. Dairy Sci. 98:7142-7152. https://doi.org/10.3168/jds.2014-9226.

Freetly, H. C., J. Nienaber, and T. Brown-Brandl. 2006. Partitioning of energy during lactation of primiparous beef cows. J. Anim. Sci. 84:2157-2162. https://doi.org/10.2527/jas.2005-534.

Goering, H. K., and P. J. Van Soest. 1970. Forage fiber analyses. USDA Agricultural Research Service handbook no. 379. US Government Printing Office, Washington, DC.
Hall, M. B. 2009. Analysis of starch, including maltooligosaccharides, in animal feeds: A comparison of methods and a recommended method for AOAC collaborative study. J. AOAC Int. 92:42-49.

Judy, J. V., G. C. Bachman, T. M. Brown-Brandl, S. C. Fernando, K. E. Hales, P. S. Miller, R. R. Stowell, and P. J. Kononoff. 2018. Energy balance and diurnal variation in methane production as affected by feeding frequency in Jersey cows in late lactation. J. Dairy Sci. 101:10899-10910. https://doi.org/10.3168/jds.2018 $-14596$.

Kronfeld, D. S. 1982. Major metabolic determinants of milk volume, mammary efficiency, and spontaneous ketosis in dairy cows. J. Dairy Sci. 65:2204-2212. https://doi.org/10.3168/jds.S0022 $-0302(82) 82483-1$.

Kuznetsova, A., P. B. Brockhoff, and R. H. B. Christensen. 2017. lmerTest package: Tests in linear mixed effects models: Version 3.0-1. Accessed Nov. 28, 2019. https://cran.r-project.org/web/ packages/lmerTest/index.html.

Linzell, J. L., and M. Peaker. 1971. Mechanism of milk secretion. Physiol. Rev. 51:564-597. https://doi.org/10.1152/physrev.1971 .51 .3 .564 .

Moe, P. W., H. F. Tyrrell, and W. P. Flatt. 1971. Energetics of body tissue mobilization. J. Dairy Sci. 54:548-553. https://doi.org/10 .3168/jds.S0022-0302(71)85886-1.

Nichols, K., J. Dijkstra, H. van Laar, S. Pacheco, H. J. van Valenberg, and A. Bannink. 2019. Energy and nitrogen partitioning in dairy cows at low or high metabolizable protein levels is affected differently by postrumen glucogenic and lipogenic substrates. J. Dairy Sci. 102:395-412. https://doi.org/10.3168/jds.2018-15249.

Nienaber, J., and A. Maddy. 1985. Temperature controlled multiple chamber indirect calorimeter-design and operation. Trans. ASAE 28:555-0560. https://doi.org/10.13031/2013.32297.

NRC. 1981. Nutritional Energetics of Domestic Animals and Glossary of Energy Terms. National Academies Press, Washington, DC

NRC. 2001. Nutrient Requirements of Dairy Cattle. 7th rev. ed. National Academies Press, Washington, DC.

Piccioli-Cappelli, F., J. Loor, C. Seal, A. Minuti, and E. Trevisi. 2014. Effect of dietary starch level and high rumen-undegradable protein on endocrine-metabolic status, milk yield, and milk composition in dairy cows during early and late lactation. J. Dairy Sci. 97:77887803. https://doi.org/10.3168/jds.2014-8336.

Reynolds, C. K., S. Cammell, D. Humphries, D. Beever, J. Sutton, and J. Newbold. 2001. Effects of postrumen starch infusion on milk production and energy metabolism in dairy cows. J. Dairy Sci. 84:2250-2259. https://doi.org/10.3168/jds.S0022-0302(01)74672 $-3$.

Rico, D. E., Y. Ying, and K. J. Harvatine. 2014. Effect of a highpalmitic acid fat supplement on milk production and apparent total-tract digestibility in high- and low-milk yield dairy cows. J. Dairy Sci. 97:3739-3751. https://doi.org/10.3168/jds.2013-7341.

Rius, A. G., J. Appuhamy, J. Cyriac, D. Kirovski, O. Becvar, J. Escobar, M. McGilliard, B. Bequette, R. Akers, and M. Hanigan. 2010. Regulation of protein synthesis in mammary glands of lactating dairy cows by starch and amino acids. J. Dairy Sci. 93:3114-3127. https://doi.org/10.3168/jds.2009-2743.

Roman-Garcia, Y., R. R. White, and J. L. Firkins. 2016. Meta-analysis of postruminal microbial nitrogen flows in dairy cattle. I. Derivation of equations. J. Dairy Sci. 99:7918-7931. https://doi.org/10 $.3168 /$ jds.2015-10661.

Sok, M., D. R. Ouellet, J. L. Firkins, D. Pellerin, and H. Lapierre. 2017. Amino acid composition of rumen bacteria and protozoa in cattle. J. Dairy Sci. 100:5241-5249. https://doi.org/10.3168/ jds.2016-12447.

Sutton, J. D., M. Dhanoa, S. Morant, J. France, D. Napper, and E. Schuller. 2003. Rates of production of acetate, propionate, and butyrate in the rumen of lactating dairy cows given normal and low-roughage diets. J. Dairy Sci. 86:3620-3633. https://doi.org/10 .3168/jds.S0022-0302(03)73968-X.

Tyrrell, H. F., and J. T. Reid. 1965. Prediction of the energy value of cow's milk. J. Dairy Sci. 48:1215-1223. https://doi.org/10.3168/ jds.S0022-0302(65)88430-2. 
van Knegsel, A. T., H. Van den Brand, J. Dijkstra, S. Tamminga, and B. Kemp. 2005. Effect of dietary energy source on energy balance, production, metabolic disorders and reproduction in lactating dairy cattle. Reprod. Nutr. Dev. 45:665-688. https://doi.org/ 10.1051/rnd:2005059.

van Knegsel, A. T., H. Van den Brand, J. Dijkstra, W. Van Straalen, M. Heetkamp, S. Tamminga, and B. Kemp. 2007a. Dietary energy source in dairy cows in early lactation: Energy partitioning and milk composition. J. Dairy Sci. 90:1467-1476. https://doi.org/10 .3168/jds.S0022-0302(07)71632-6.

van Knegsel, A. T., H. Van den Brand, J. Dijkstra, W. Van Straalen, R. Jorritsma, S. Tamminga, and B. Kemp. 2007b. Effect of glucogenic vs. lipogenic diets on energy balance, blood metabolites, and reproduction in primiparous and multiparous dairy cows in early lactation. J. Dairy Sci. 90:3397-3409. https://doi.org/10.3168/jds .2006-837.
Van Soest, P. J., J. B. Robertson, and B. A. Lewis. 1991. Methods for dietary fiber, neutral detergent fiber, and nonstarch polysaccharides in relation to animal nutrition. J. Dairy Sci. 74:3583-3597. https://doi.org/10.3168/jds.S0022-0302(91)78551-2.

Weiss, W. P., N. R. St-Pierre, and L. B. Willett. 2009. Varying type of forage, concentration of metabolizable protein, and source of carbohydrate affects nutrient digestibility and production by dairy cows. J. Dairy Sci. 92:5595-5606. https://doi.org/10.3168/jds.2009 -2247 .

\section{ORCIDS}

D. L. Morris ํㅜ https://orcid.org/0000-0001-6347-2804

K. E. Hales ๑ https://orcid.org/0000-0003-3344-9800

P. J. Kononoff $\odot$ https://orcid.org/0000-0001-6069-2174 